\title{
Contribuições ao debate sobre autonomia e liberdade de expressão em tempos de convergência e Educação Aberta
}

\section{Contributions to the debate on autonomy and freedom of expression in convergence times and Open Education}

\author{
Andrea Cristina Versuti (UFG | Jataí) ${ }^{1}$ \\ Marco Aurélio R. da Cunha e Cruz (Direito $\mid$ Alfa) ${ }^{2}$ \\ Carlos Costa (Unit) ${ }^{3}$
}

Recibido: 10-12-14

Aprobado: 15-01-15

\section{Resumo}

O objetivo deste texto é apresentar um contributo das novas formas de comunicação, expressão, interação, colaboração e integração para as potencialidades da construção do conhecimento, por meio dos recursos educacionais abertos, na atual

\footnotetext{
${ }^{1}$ Doutora em Educação, Ciência e Tecnologia | UNICAMP, Docente | Pesquisadora do Programa de PósGraduação em Educação da UFG-Regional Jataí. 1.2. Publicaciones de Andrea Cristina Versuti: : RENO, D. P.; VERSUTI, A. C.; GONCALVES, E. M.; GOSCIOLA, V. Narrativas transmídas, diversidade social, discursiva e comunicacional. Palabra Clave, v. 14, p. 201-215, 2011; VERSUTI, A. C.; GOSCIOLA, V. Narrativa Transmídia e sua potencialidade na educação aberta. In: Alexandra Okada. (Org.). Recursos Educacionais Abertos e Redes Sociais. 2. ed.São Luis: Editora UEMA, 2014, v. 1, p. 278-284; VERSUTI, A. C.; BERALDO, R.; GOSCIOLA, V. Formação de Professores: transmídia, conhecimento e criatividade. 1. ed. Recife: EDUFPE, 2014.

${ }^{2}$ Doutor em Direito Constitucional | Universidad de Sevilla, Docente | Pesquisador do Curso de Direito das Faculdades Alves Faria (Direito | Alfa), Bolsista FUNADESP. Publicaciones de Marco Aurélio Rodrigues da Cunha e Cruz: CUNHA E CRUZ, M. A. R. A evolução conceitual da liberdade de expressão na jurisprudência do Supremo Tribunal Federal. Revista Espaço Jurídico, v. 11, p. 402-421, 2011; CUNHA E CRUZ, M. A. R.; COSTA, C. Um estudo do caso ARE 660861 (STF): breves considerações sobre os cenários internacional e nacional do controle de conteúdo pelo provedor de Internet. In: PAGLIARINI, Alexandre Coutinho; SOUZA, José Washington Nascimento de (Org.). Direito econômico e socioambiental. 1ed. Rio de Janeiro: GZ EDITORA, 2014, v. , p. 315-342; CUNHA E CRUZ, M. A. R. Sobre os estudos acerca da docência e construção de conhecimento na EAD. In: BORGES,F.T.; VERSUTI,A.C.; PORTO,C. M.;BARRETO,R.A.D.N. (Org.). Formação de professores: transmídia, conhecimento e criatividade. 1ed.Recife: Editora Universitária/UFPE, 2013, v. 1, p. 7-16.

${ }^{3}$ Mestre em Direitos Humanos pela Universidade Tiradentes, Especialista em Processo Civil pela Universidade Estadual de Santa Cruz, Docente da Universidade Tiradentes - UNIT. Publicación de Carlos Costa: CUNHA E CRUZ, M. A. R.; COSTA, C. Um estudo do caso ARE 660861 (STF): breves considerações sobre os cenários internacional e nacional do controle de conteúdo pelo provedor de Internet. In: PAGLIARINI, Alexandre Coutinho; SOUZA, José Washington Nascimento de (Org.). Direito econômico e socioambiental. 1ed. Rio de Janeiro: GZ EDITORA, 2014, v. , p. 315-342.
} 
cultura da mobilidade e da convergência. Para alcançar este fim, o escrito tematiza a importância da releitura da liberdade de expressão como um veículo de alargamento democrático e plural das demais liberdades; o impacto da Internet e outras formas de pensamento emergentes no desenvolvimento da autonomia do sujeito; a caracterização do cenário atual da cultura convergente com suas possibilidades para uma Educação Aberta que prime pelo estímulo à inteligência coletiva e à cultura participativa, para ao final apontar algumas considerações finais.

Palavras-chave: Liberdade de Expressão, Internet, Autonomia, Convergência, Educação Aberta.

\begin{abstract}
This paper aims to present a contribution of new forms of communication, expression, interaction, collaboration and integration for the potential construction of knowledge, through open educational resources, in the current culture of mobility and convergence. To achieve this end, this text focus on the importance of re-reading of freedom of expression as a democratic enlargement vehicle and plural of other freedoms; the impact of the Internet and other emerging thinking in the development of the autonomy of the subject; the characterization of the current scenario of convergence culture with its possibilities for Open Education that stimulates collective intelligence and participatory culture.
\end{abstract}

Key-words: Freedom of Expression, Internet, Autonomy, Convergence, Open Education.

\title{
Introdução
}

Embora seja incontroversa a afirmativa de que no cenário da mídia digital houve uma significativa mudança no processo inter-relacional (Sibila, 2002; Castells, 2003), é preciso interpretar com cautela as assertivas utópicas, proféticas e deterministas das consequências das relações informatizadas, pois as tensões e rupturas estão a todo o momento reconfigurando a subjetividade e a intersubjetividade, de modo que ostentar o discurso antagônico e contraditório do passado não pode se revestir de conotação definitiva (Primo, 2013; Neves, 2007).

Neste sentido, pode-se abordar, como observam Molinaro e Ruaro (2014), "a possibilidade da tecnologia determinar a sociedade", descrita como um determinismo tecnológico ou "a possibilidade de identificação na sociedade da tecnologia", um determinismo social (recordando a memorável paráfrase de Umberto Eco de apocalípticos e integrados). O determinismo tecnológico se contrapõe à teoria da construção social da tecnologia (SCOT 
- social construction of technology), que admite que a ação humana é a que produz a tecnologia, reforça a ambiência social, pois defende que a tecnologia não pode ser compreendida e efetivamente utilizada fora de seu contexto sociocultural.

De certo, pode-se vislumbrar a opção por um alinhamento teórico por uma ou por outra perspectiva, mas há de se advertir que a tecnologia e a sociedade representam uma tecnologia que está imersa nos propósitos sociais de criatividade, e uma sociedade que se conduz pela mediação tecnológica. A compreensão sobre esta aproximação há de ter em conta a influência da tecnologia no comportamento social, no trabalho, nas instituições, nos direitos humanos, na Educação e nos resultados sociais do uso desta.

O texto a seguir não negligencia as perspectivas apocalípticas da assunção da tecnologia, mas não as prioriza. O objetivo é apresentar um contributo das novas formas de comunicação, expressão, interação, colaboração e integração para as potencialidades da construção do conhecimento, por meio dos recursos educacionais abertos, na atual cultura da mobilidade e da convergência. Para alcançar este fim, o escrito tematiza a importância da releitura da liberdade de expressão como um veículo de alargamento democrático e plural das demais liberdades; o impacto da Internet e outras formas de pensamento emergentes no desenvolvimento da autonomia do sujeito; a caracterização do cenário atual da cultura convergente com suas possibilidades para uma Educação Aberta que prime pelo estímulo à inteligência coletiva e à cultura participativa, para ao final apontar algumas considerações finais.

\section{Liberdade de Expressão e Internet: autonomia, decidibilidade e responsabilidade}

A necessidade de interação como antecedente lógico causal para a liberdade já era comungada pela Política de Aristóteles (2000), ao asseverar a essencial sociabilidade do ser humano e a "palavra" (no sentido de expressão) como signo de inteligibilidade que o aparta de um estado de animalidade. Sob outra perspectiva, Rosseau (1999) testifica que o sujeito constrói sua liberdade saindo do estado da natureza e se relacionando, como integrante do corpo político. Pauta-se no consciente e na crítica, que permitem o indivíduo conhecer a si mesmo para em seguida se transportar para o lugar dos outros e, por fim, identificar as relações que pretende manter ou se afastar, graças às relações sociais, corolário da comunicação. No ensaio sobre a origem das línguas, Rosseau (1997) credita à palavra (no sentido comunicacional) como a primeira instituição social, pois confere ao ser humano o instrumento de reconhecimento dele próprio como sensível, pensante e semelhante ao próximo. 
Não dispensando as reflexões clássicas aristotélicas, tampouco as contratualistas rosseaunianas, não se pode olvidar que a condição de ser livre, para Larenz (1993), é pressuposto lógico e antecedente da liberdade, na medida em que esta não é inerente à condição humana e sim fruto da resistência da subjetividade individual que é criada e limitada pela vontade coletiva, isto é, relacional. Tendo em vista esta visão relacional de liberdade de Larenz (1993), oportuno é resgatar que Mill (2011) não parte das bases filosóficas do querer para compreender as liberdades individuais e sim da sua natureza social ou civil, defendendo uma liberdade negativa em que as pessoas possam raciocinar, agir e se expressar, libertas dos padrões e impedimentos estabelecidos pela massa ou por outros indivíduos.

À vista disto, na concepção de Stuart Mill (2011) a liberdade do indivíduo sobre si próprio depende da não intervenção do Estado sobre a sua consciência, permitindo, assim, a livre construção da opinião e da individualidade. Acredita que o desenvolvimento do ser humano depende de um espaço mínimo indene às interferências externas, seja estatal ou dos seus pares, isto é: a liberdade de pensamento. Esta liberdade também compreende o direito de não sofrer constrangimento em razão das próprias opiniões e de expressar suas ideias sem as amarras da censura, consistindo o diálogo e o confronto das diversas opiniões a matéria-prima necessária para a contínua evolução do indivíduo enquanto ser racional.

De fato, segundo Locke (2001) e Habermas (2000) desde a Antiguidade o conflito entre as liberdades e a intervenção do Estado vem sendo objeto de discussões políticas e filosóficas. Não obstante, juridicamente, foi em 1791 a mais fulgurante proclamação formal da liberdade de expressão com a Declaração dos Direitos do Homem e do Cidadão, onde se lê no seu art. 11 que "a livre comunicação dos pensamentos e das opiniões é um dos direitos mais preciosos do homem; todo cidadão pode, então, falar, escrever, imprimir livremente, respondendo pelo abuso desta liberdade nos casos determinados pela lei" (Crettela Júnior, 1974: 93-94).

No entendimento de Bobbio (2006) e Locke (2001) em seus primórdios, a liberdade sob a ótica da doutrina liberal tradicional era definida como uma proteção àquele que detém o poder, o Estado. Sob este aspecto, é mais caro à liberdade o controle dos abusos de poder e das funções do Estado do que os instrumentos (direitos fundamentais) positivados no Estado de Direito que coíbem o exercício arbitrário do poder. Assim, a liberdade que tutela a "esfera" privada contra as intromissões por parte do poder público é chamada de liberdade negativa, que, por sua vez, exerce um duplo papel limitador: restringir as intervenções estatais na liberdade dos indivíduos e o poder de agir destes desprovidos das barreiras impostas pelo Estado. Verifica-se, dessa forma, uma relação assimétrica entre o poder e a liberdade, na medida em que o 
crescimento de um acarreta a diminuição do outro e vice-versa. Neste sentido, uma parte da existência humana, o mínimo, deveria permanecer independente do controle, sendo o Estado reduzido ao que Lassale descreveu como as funções de um vigia ou de um guarda de trânsito (Berlin, 2002).

Por seu turno, Bobbio (2006: 20) propõe que a liberdade negativa seja "entendida como a esfera de ação em que o indivíduo não está obrigado por quem detém o poder coativo a fazer aquilo que não deseja ou não está impedido de fazer aquilo que deseja". Nessa direção, o entendimento de Pontes de Miranda (1979: 248) é o de que na concepção primeva da liberdade a preocupação tinha como ponto de partida o indivíduo, isto é, "até onde a liberdade pode ir e até onde pode ir o Estado". A liberdade de expressão, partindo desta consideração liberal, é uma liberdade frente ao Estado e se enlaça nos direitos de resistência ou de oposição perante o Estado. Este vínculo entre a liberdade de expressão e a crítica política se fez mais latente nos primeiros textos revolucionários burgueses, que adjetivaram esta liberdade de irrenunciável frente à situação inquisitorial do ancien régime (Machado, 2002).

Com efeito, junto a este primeiro aspecto individualista-liberal-negativo, a liberdade de expressão viu seu conteúdo se converter em uma conditio sine qua non da democracia (Dahl, 2009). Não se reduziu mais na visão de exigência/ condição individualista do cidadão, mas contribuiu organicamente para as aspirações da sociedade política guarnecida pelo regime democrático. Assumiu um lugar central no processo de constitucionalização dos direitos fundamentais, dada sua função instrumental de afirmação da liberdade individual de pensamento e de opinião, desembocando-se na garantia da autodeterminação democrática da sociedade política.

Nessa perspectiva democrática, a liberdade negativa é uma situação de poder expressar opiniões próprias sem as amarras da censura (Bobbio, 1993). Ou "não está em ação nenhuma força coercitiva que o impeça de fazer alguma coisa (Chomsky, 2005: 366). De outro lado, a liberdade positiva está relacionada à autonomia e à decidibilidade, isto é, a situação de poder tomar decisões sem ser determinado pela vontade alheia e de externar suas ideias perante o Estado e os particulares (Alexy, 2008). Sustenta Berlin (2002) que o sentido positivo da liberdade consiste no desejo do indivíduo de ser responsável pelas suas escolhas e capaz de explicá-las a partir de suas ideias e propósitos, visto que para ter liberdade não basta a ausência de interferência, mas sobre ela também insurge uma responsabilidade.

A liberdade positiva denominada por Habermas (2000: 27) de liberdade subjetiva dos indivíduos "funda-se, por um lado, no direito do indivíduo de discernir como válido o que ele deve fazer; por outro, fundam-se na exigência de que cada um persiga os fins do bem-estar particular, em consonância com o bem-estar de todos os outros". Tais pensamentos teóricos caminham 
na mesma direção do raciocínio de Alexy (2008), segundo o qual os direitos fundamentais são democráticos na medida em que garantam condições para a realização da liberdade real (fática), indispensável para o exercício da liberdade jurídica e da manutenção das condições funcionais do processo democrático. Representa, pois, a liberdade de expressão uma dimensão institucional, pois, além de proteger um interesse individual, floresce como garantia de um legítimo interesse constitucional que é, nos dizeres de Robert A. Dahl (2009), a aquisição de uma compreensão esclarecida pelos cidadãos de possíveis atos e políticas do governo, a qual, deste modo, fomenta a participação na direção política da sociedade. Esta liberdade positiva que incentiva a participação esclarecida dos cidadãos na vida política é a projeção da continuidade da liberdade de expressão através da liberdade de informação, conteúdo e espécie daquela juntamente com a liberdade de opinião, conforme dispõe a Declaração Universal de Direitos Humanos de 1948 (art. 19) e o Pacto Internacional dos Direitos Civis e Políticos de 1966 (art. 19).

De fato, um dos grandes motores da civilização foi a liberdade de se expressar, de exteriorizar sua reflexão interna, a sua posição axiológica sobre a realidade. Nesta trajetória, o pensamento reflexivo por si mesmo, livre de interferências externas é a porta de saída das demais liberdades, pois esta é fundamento e alicerce de todas as outras liberdades humanas. Transcender as barreiras da individualidade somente é possível porque dentre os animais somente o ser humano é quem possui o discurso articulado. Como aduz Paulo Freire (2011) a partir do momento em que os seres humanos foram "criando" o mundo, inventando a linguagem e se habilitando a inteligir o mundo, criaram por consequência a necessária comunicabilidade do inteligido.

Com a comunicação e a interação, o ser humano consegue armazenar o que já adquiriu e se desenvolver enquanto elemento integrante da natureza, transmudando-se, para a condição de ser inteligível, uma vez que o pensamento exige conhecimento e este caminha de mãos dadas com a liberdade. O ser humano percebeu que não somente existe ou vive e sim coexiste e convive, dependendo dos outros para se identificar, construir e desenvolver. Isso porque, como afirmado por Paulo Freire (2011: 115) "não há inteligência da realidade sem a possibilidade de ser comunicada".

Nesta transição do isolamento para o relacionamento inicia-se através dos primórdios meios de comunicação, isto é, o fluxo dos pensamentos e ideias, tão importantes para vida em sociedade quanto o é a liberdade física. É por essa razão que Carvalho (1994:1) comenta que "a história do homem é a história de sua comunicação com os demais; é a história da luta entre as ideias; é o caminhar dos pensamentos".

Em despretensiosa síntese, esta jornada começou com a linguagem oral (oralidade primária), primeiro instrumento de socialização que potencializou a 
interação e as possibilidades dos indivíduos. Posteriormente surgiu a agricultura diminuindo o lapso temporal entre as comunidades e a terra, fazendo com que as pessoas tivessem mais tempo para se trocar experiências. Desta relação mais próxima com terra surgiram as cidades, locus em que foi desenvolvido a linguagem escrita que possibilitou, simultaneamente, potencializar a comunicação e armazenar conhecimentos que até então ficavam perdidos e isolados no passado (Neves, 2007).

Paralelamente a evolução das ferramentas socializadoras, a velocidade da transmissão das informações influenciou de sobremaneira a emancipação dos indivíduos e, consequentemente, o potencial libertário da comunicação que, sucessivamente, teve como ponto de partida a tração animal evoluindo com os tambores africanos, as caravelas, o telégrafo, o telefone, os jornais e com as primeiras mídias eletrônicas - rádio e a televisão -, para então atingir a infinitude de crescimento com a Internet (Neves, 2007; Gleick, 2013).

De fato, as relações sociais são porosas e a sua recategorização é fruto do fluxo e acúmulo de informações, bem como das diferentes óticas em que são constituídas. Tanto o compartilhamento quanto as formas de recepcionar as informações foram se amoldando com a evolução das técnicas, de modo a surgir ao longo das gerações distintos meios de interação social, no entanto, todos conduzidos pelo trilho da comunicação, veículo da liberdade de expressão (Spadaro, 2013).

Ao longo da história cada tecnologia representou rupturas e reestruturações nas relações sociais. Assim foi se delineando um novo padrão social com a invenção da máquina a vapor, da eletricidade, do telégrafo, do telefone, do rádio e televisão, no entanto, a Internet é e está sendo um divisor de águas nas técnicas de informação e comunicação, constituindo uma nova forma de organização social que impôs uma significativa alteração do processo de interação humana.

Desde sua proposta militar embrionária "Advanced Research Projects Agency" (ARPANET), seu uso pelas universidades e institutos de pesquisa com a tecnologia de conexão TCP/IP, sua maior acessibilidade no final dos anos de 80 com a criação do modelo hipertexto através do protocolo Hyper Text Transfer Protocol (HTTP) e a linguagem Hyper Text Markup Language (HTML), até a sua popularização, a intenção da Internet não destoa da conexão, comunicação e interação entre os seres humanos (Castells, 2003; Pisani; Piotet, 2010).

A releitura da liberdade de expressão a partir da Internet contribui para a emancipação do indivíduo, que segundo Habermas (2000) somente ocorre quando este adquire a liberdade de agir conforme suas reflexões. De outro lado, a mutação do conteúdo da liberdade de expressão experimentada no ambiente on line e o ideal libertário e colaboracionista proposto pela Internet exigem dos 
participantes uma escolha ética, que consequentemente gera responsabilidade e alteridade (Dussel, 1996). De fato, os novos espaços de ambientação da liberdade de expressão requerem "um código deontológico que valoriza a autonomia, a liberdade da palavra, a gratuidade, o consenso e a tolerância" (Cardon, 2012: 8).

Pérez Luño (2002) recorda que "apocalípticos" e "integrados", por Umberto Eco, são duas atitudes básicas frente à cultura de massas e à sociedade tecnológica. Enquanto a apocalipse é uma obsessão do dissenter, a integração é a realidade concreta daqueles que não dissentem. Os apocalípticos têm o mérito de captar e denunciar os impactos perversos de determinados usos das tecnologias. É uma atitude que peca pela unilateralidade, porque refuta cegamente os avanços e virtualidades do progresso. Não menos satisfatória e unilateral é a atitude dos integrados, que adoram o "novo" só pelo fato de ser novo. Esta posição acrítica representa uma aceitação servil ante os riscos implícitos em determinados abusos das tecnologias e pode ter perigosas consequências. Nesta postura integrada, há quem se sinta satisfeito e considere normal que na atualidade já não exista nenhum âmbito da vida pública e privada, individual ou social que não esteja condicionada direta ou indiretamente pela técnica. Neste contexto, Pérez Luño (2002) pugna por uma ética jurídica ciberespacial, nem "apocalíptica" tampouco "integrada", pois normas ou programas éticos dirigidos a evitar as condutas perturbadoras realizadas pelos cibernautas devem gerar e estimular atitudes de consciência coletiva sobre o respeito às liberdades e aos bens ameaçados por uma utilização indevida do ciberespaço, e contribuir para a formação de vínculos solidários para a prevenção de crimes informáticos e a ajuda ao seu descobrimento. A difusão capilar das redes comunicativas pode conduzir à produção de regras jurídicas consuetudinárias sobre seu uso, nas que os códigos de conduta cuja eficácia se paute na convicção dos sujeitos e na sua responsabilidade solidária prevaleçam sobre dimensão coativa das normas baseada na autoridade de um poder centralizado.

Não destoam deste raciocínio Molinaro e Ruaro (2014), que não advogam por uma intervenção incisiva no ethos das novas relações sociais, mas sustentam uma postura do Direito como mediador e regulador soft law desta inevitável interdependência entre Tecnologia e Sociedade. Ressaltam que o Direito há de ter um caráter mais instrumental, para garantir a criatividade, a engenhosidade e a capacidade de adaptação permanente da pesquisa tecnológica, evitando a predominância unilateral dos interesses econômicos e oportunizando uma proteção socioambiental, cultural e econômica (Molinaro, Ruaro: 2014: 56). "Esta postura de menos intervenção e mais autorregulação pode ser a responsável pelapotencialização dos dois atuais subsídios da Internet: a estruturação libertária e colaboracionista da rede". 
Do espírito aberto, heterogêneo e horizontal que desenhou os primeiros contornos da Internet e que persiste até os dias atuais vislumbra-se na prática pelo engenhoso sistema descentralizado de tráfego das informações que permite a fluidez e a inovação dos conteúdos em cada extremidade da rede, afastando-se de um comando único de controle e criação, próprios das mídias estáticas tradicionais. Esta plataforma neutra, aberta e com linguagens diversificadas foi potencializada com a criação da Web (World Wide Web), uma das aplicações mais populares da Internet que com esta não se confunde. Para Castells (2003) e Leonardi (2005) a Internet é concebida como a rede mundial que conecta todos os computadores entre si. Sob a ótica de Pisani e Piotet (2010), a Web é vista como "um conjunto de documentos modificáveis, igualmente conectados entre si".

Pierre Lèvy (2000: 5) ao teorizar sobre a terceira onda das tecnologias intelectuais - a informática - profetiza que as relações interpessoais estarão inseridas num "campo de novas tecnologias intelectuais, aberto, conflituoso e parcialmente indeterminado", em que "nada está decidido a priori". De certo, o filósofo se referia as tecnologias de informação sendo, dentre as várias técnicas, as de transmissão e tratamento das mensagens responsável pela mudança na forma de pensar, agir e interagir.

Sustenta ainda que a utilização das técnicas da informática para comunicação faz emergir uma nova tecnologia de inteligência denominada oralidade digital que graças a rede digital de serviços integrados (RDSI) é possível a confecção, tratamento, transferência e capacidade de armazenamento das informações através dos computadores (Lèvy, 2000). Observa-se que esta rede hipermidiática (RDSI) que possibilita a circulação de informações e a interatividade em rede, guardada as devidas proporções, exercia o papel da Web 2.0.

Um modelo digital não é lido ou interpretado como um texto clássico, ele geralmente é explorado de forma interativa. Contrariamente à maioria das descrições funcionais sobre papel ou aos modelos reduzidos analógicos, o modelo informático é essencialmente plástico, dinâmico, dotado de uma certa autonomia de ação e reação (Lèvy, 2000:74).

Esta brevíssima descrição da Internet, por si só, clarifica que embora a natureza militar tenha tatuado a arquitetura inicial da Internet, já estava presente, ainda que de forma perfunctória e restrita, a noção de conectividade e a comunicação como objetivo direto e imediato da grande rede desde o nascedouro até os tempos atuais. Outro fato indicado como incontestável por Castells (2003) é que a Internet foi fruto da combinação entre a revolta estadunidense com os valores e ideais impostos pelas sociedades industriais ocidentais com o espírito de eficiência e qualificação das pesquisas científicas.

Mas não só a comunicação sofreu transformações com a Internet como 
também os comportamentos de comunicação, as relações interpessoais. Conceber a Internet apenas e tão somente como a digitalização das mídias eletrônicas antecedentes é por demais simplista e excludente de qualquer caráter inovador. Como visto a Internet não se reduz a uma nova geração de mídia propagadora de informação ou de comunicação entre as pessoas. Diferente das mídias tradicionais, o ambiente da rede é de movimentos não lineares, fluido, poroso, aberto para amadores e profissionais, com efeitos imprevisíveis, onde não só é possível o acesso às informações como a interação com aquelas, de modo a romper a barreiras dos padrões conservadores e não emancipatórios consolidados no Século XX, tornando a Internet um novo palco de interação e comunicação neutro e indômito, vez que as consequências do uso desta plataforma são imprevisíveis (Acedo, 2012; Spadaro, 2013). Isso porque a Internet enquanto um meio de comunicação possui peculiaridades que a diferem dos demais: "a não linearidade; o imediatismo do aqui agora; a tendência à heterogeneidade, a fragmentação e a exaltação das diferenças; a conformação de uma estrutura social em redes e comunidades virtuais; a atomização da informação; e a possibilidade de interatividade" (Acedo, 2012: 147).

Certamente, o fenômeno da informatização das relações sociais é indissociável da evolução na Internet. No início da popularização da Internet, havia deslumbre com a simples navegação e acesso aos conteúdos dos sites criados e mantidos por especialistas. Após a criação da Web 2.0 em meados de 2004, os sujeitos saíram da condição de receptivos e passaram a interagir com as informações, seja criando, disponibilizando, comentando e trocando informações, e graças a esta participação ativa e efetiva são denominados de "web atores" (Pisani; Piotet, 2010). Ademais, com a Web 2.0 foi introduzida uma forma de comunicação mais participativa, a chamada comunicação colaborativa que permite aos destinatários das informações dos meios de comunicação tradicionais a participar da criação e edição dos materiais divulgados na rede (Santaella, 2010).

Curiosamente, o ideal empresarial de desmaterializar os atos de comércio foi superado pela utilização da grande rede como instrumento e local onde se estabelecem relações entre pessoas, entre informações e entre estas com aquelas. O fluxo das informações quando disponibilizadas na Internet não se limitam as redes sociais daquele que a criou, elas trafegam em outras redes e se relacionam com outras informações, de modo a permitir a interação e participação de todos no constante processo de reelaboração dos conteúdos. A Web 2.0 resignificou não só a sistemática da construção da informação, como também o sentido de publicar. "Publicar significa participar, isto é, compartilhar" (Spadaro, 2013:11)

Significa dizer que nas relações informatizadas todos os participantes são, simultaneamente, emissor e receptor, criador e destruidor, editor e difusor 
das informações, não existindo um único detentor da informação. De igual modo, as relações informatizadas permitem o experimento de novas formas de interação e construção das informações, não estabelecendo distinções entre destinatário e emitente, vez que "todos os que participam deste processo podem exercer todos os papéis" (Aparici, 2012: 27).

A Teoria Ator-Rede (TAR) desenvolvida por Bruno Latour acerca do funcionamento da sociedade a partir da ideia de rede explica esta interatividade proporcionada pelos meios digitais. Entendida como o produto que é criado no processo de interação composta por inúmeros atores humanos e não humanos, a concepção de rede não é a de arquitetura, "não é o que conecta, mas o que é gerado pelas associações" (Lemos, 2013: 53). Em outras palavras, equivale aos conteúdos que são construídos e remodelados em cada relação intersubjetiva travada nas redes sociais. O produto final que é construído desta relação dinâmica entre as pessoas e destas com os elementos não humanos segundo a TAR pode ser equiparado na atual Sociedade em Rede (Castells, 2003) como o conhecimento coletivo decorrente das interações com as outras pessoas e destas com as diversas informações (elemento material) ou com a inteligência coletiva (Lèvy, 2000). Além da mudança na construção das informações, a sua estrutura homogênea cedeu espaço para a capacidade técnica de convergir em um único conteúdo, textos, imagens e sons. Este conteúdo multimídia é o centro das redes e objeto das relações informatizadas.

Não só a subjetividade, como também a sociabilidade, estão sendo remodeladas, distanciando-se do padrão industrial da identidade fixa, estável e com espírito de pertencimento. Ratificando este caráter cosmopolita das relações informatizadas, Sibilia (2002: 35) afirma que "o sujeito é definido cada vez menos em função do Estado-nação como território geopolítico no qual nasceu ou reside, e cada vez mais em virtude do seu relacionamento com as corporações do mercado global". A liberdade para construir e (re) construir as subjetividades através das relações estabelecidas na rede resulta da sua dimensão criativa, colaborativa e interativa, permitindo aos sujeitos a criar, recepcionar e interagir com os conteúdos, modificando-os e compartilhando nos canais de comunicação.

É importante destacar que a tecnologia propriamente dita presente na Internet não é questionada enquanto aparato técnico, pois ela adquiriu uma determinada "transparência" "que lhes permite lidar com pessoas, informações, jogos, serviços, aplicações e amigos. Por isso é necessário considerarmos as implicações trazidas pela sua utilização sobre a percepção da realidade

\footnotetext{
${ }^{4}$ Termo utilizado por Don Tapscott em Geração Digital. Makron Books, 1999.p.37. "Nesse sentido, a tecnologia é completamente transparente para eles (...). Para as crianças é como usar um lápis. Os pais não falam em lápis, falam em escrever. E as crianças não falam da tecnologia, falam em brincar, construir um site Web, escrever aos amigos".
} 
social, isto é, ao nos conectarmos com as informações por meio da Internet estão ocorrendo mudanças externas, mas também internas ${ }^{5}$. É fundamental reconhecer que o computador tornou-se um novo ambiente cognitivo.

Podemos dizer que um novo conjunto de valores está surgindo no bojo destas transformações no processo de comunicação. Apesar das diferentes classes sociais, religiões e perspectivas, alguns padrões de pensamento e ação emergentes ultrapassam as fronteiras nacionais, econômicas e sociais. O processo de comunicação, assim como a transmissão de qualquer tipo de conteúdo, deve ser concebido como uma articulação de práticas de significação, num campo de forças sociais pertencentes a certo conjunto de sentidos disponíveis na sociedade.

Um fato decorrente deste processo é que a Internet além de ser um recurso de entretenimento e diversão tornou-se mais uma importante referência no processo de aprendizagem e construção do conhecimento; justamente por ser um meio que combina o poder de outras mídias (jornais, revistas, rádio, TV), abrangendo uma grande variedade de tecnologias de computação, telecomunicações, entretenimento, interligando texto digitalizado, sons, imagens e vídeo.

Sem dúvida, as experiências compartilhadas pela internet e por outras mídias reformulam e recriam os padrões culturais de construção dos significados formando, em interconexão coletiva, um sistema de correspondência simbólica generalizada que se encontra em contínua transformação. No ciberespaço estão interconectadas, portanto, todas as fontes de signo sejam estas - não humanas (sensores e gravadores) ou humanas (pessoas e grupos) (Pellanda, 2008). Sendo assim, a instauração coletiva do sentido será realizada cada vez mais em ambientes e domínios inteligentes que se reconstroem rapidamente, onde todas as fronteiras são colocadas em questão.

É justamente neste contexto, caracterizado por Santaella (2007) como tecnocultura, que surge uma determinada condição social em que novas configurações de linguagens e tecnologias se tornam princípios organizadores, e no qual, os indivíduos e as organizações encontram-se cotidianamente expostos às mais diferentes interfaces: livros, computadores, celulares, revistas, utilizando-as para os mais diferentes fins: divertir, educar, vender de produtos a ideias e também para contar estórias. Ainda para esta autora, as tecnologias, os equipamentos e as linguagens que circulam no ciberespaço são propiciadores de uma lógica cultural denominada "Cultura das mídias" (cultura do disponível), um período de passagem entre a cultura de massa e a mais recente cibercultura (cultura do acesso) e que apresenta como principal característica o consumo personalizado e individualizado de mensagens. É justamente este

\footnotetext{
${ }^{5}$ Considerações defendidas por Pierre Lèvy em: As Tecnologias da Inteligência. RJ: 34, 1993. "Introdução"p. 7. O autor tenta mostrar que a técnica está sempre associada a um contexto social mais amplo. As mudanças tecnológicas precisam ser pensadas e avaliadas, pois é a partir destes novos mecanismos que se organiza a vida cotidiana e são construídas a subjetividade dos indivíduos.
} 
processo intermediário, segundo a autora, que permitiu ao receptor buscar sua informação e entretenimento, saindo da inércia (Santaella, 2007).

As relações informatizadas de comunicação e a produção colaborativa do conhecimento estabelecida "em diferentes momentos e locais determinados, sem, contudo, estar ela mesma presa a um lugar ou tempo em particular" é o que Pierre Lèvy (1999: 47) denomina de cibercultura, sendo as redes sociais, por sua vez, um grande exemplo desta cultura virtual. Mas esta perspectiva da cibercultura não pode se demitir de ser contextualizada na mobilidade comunicacional e, por conseguinte, na presente convergência intermidiática que a ambienta.

\section{Mobilidade e Cultura da Convergência}

Segundo Santaella (2007), a era da comunicação móvel é marcada pelo desaparecimento progressivo dos suportes, o que faz com que a comunicação, os fluxos dos signos e as trocas de informação se desprendam dos lugares fixos. Estas novas formas de comunicação interferem diretamente na nossa percepção cotidiana, seja do tempo, do espaço, seja dos modos de viver e aprender. Isto ocorre não apenas porque o mundo online propicia espaços e interfaces que ajudam a sustentar a programação das outras mídias de massa, mas porque o processo de acostumar-se à nova realidade das comunicações em rede tem um efeito salutar em nossas mentes (Johnson, 2001).

Esse sistema em rede, desprendido dos suportes fixos, possibilita um grande leque de criatividade e liberdade, deixando os sujeitos livres para criarem suas próprias redes de relacionamentos, de trabalho, de estudos e diversão. Estar na rede é estar em outro movimento por entre lugares, espaços e experiências. As tecnologias móveis, que convergem mídias e linguagens, nos permitem hoje estar em mobilidade física e virtual, o que antes não era possível ao utilizar, por exemplo, os computadores do tipo desktop, pois com estas máquinas o corpo permanecia imóvel enquanto navegávamos pelos hipertextos virtuais visitando lugares distantes.

Os celulares computadorizados multifuncionais cada vez mais velozes tornaram-se "pequenas criaturas sensíveis, quase vivas" (Santaella, 2007: 232) ou talismãs simbólicos colados ao nosso corpo, respondentes ao nosso toque como uma prótese portátil, personalizada e amigável, e nos permitem acessar qualquer pessoa em qualquer parte do mundo ou experienciar a presença - ausência, a cooperação com vizinhanças virtuais e a troca de arquivos. Com eles visualizamos a emergência simultânea do conceito de mobilidade, a vivência da ubiqüidade e do nomadismo por meio de uma tecnologia colaborativa personalizada, pois, para Santaella (2007: 234), 
"não é o equipamento que necessariamente define a mobilidade, mas o tipo de comunicação", comunicação esta caracterizada pela disponibilização, exposição, troca e colaboração (Augé, 1990).

Nas palavras de Santaella (2007: 127) "a cultura da mobilidade é fruto da revolução digital e mistura o ciber com o físico em uma urdidura nova, denominada como "espaços intersticiais". Sendo assim, a mobilidade deve ser refletida a partir de um cenário convergente.

O termo convergência está bastante presente em diversos discursos ofertando diferentes sentidos e significados. No dicionário Houaiss de língua portuguesa convergência significa o "que converge; qualidade ou disposição do que é convergente; direção para um ponto comum (...) aproximação, centralização, concentração, confluência, encontro, junção" (Houaiss; Villar, 2009: 542). No campo da tecnologia da informação, convergência aparece como sendo uma combinação de vários serviços e mídias.

Tais definições nos remetem às ideias de sinergia, aproximação, concentração, confluência. Em um primeiro momento, podemos nos remeter apenas ao desenvolvimento de aparatos tecnológicos e dispositivos cada vez mais modernos que têm a possibilidade integradora de cooptar as linguagens de várias mídias de uma vez, a exemplo dos telefones celulares. No entanto, pretendemos neste item do nosso artigo, discutir a convergência de forma mais ampla, para além dos dispositivos tecnológicos. Entendemos que a convergência vem se fazendo presente na vida dos sujeitos que interagem com as mídias, ou seja, este cenário convergente modifica de forma significativa as relações com o pensamento, com a tecnologia e principalmente interfere em nossas interações sociais e simbólicas.

É profícua para esta reflexão a definição fundamentada na sincronicidade, de Octavio Paz, para quem compreender o conceito de convergência é compreender o Tempo, e a complexidade do Tempo de convergência "reside na assimilação da fusão do antes e do depois em um instante sempre presente. Em seu texto, a Arte de Convergência, o poeta define como sendo “(...) o cruzamento de tempos, espaços e formas (Paz, 1991: 180).

Para Elisabeth Corrêa (2007), o conceito de convergência pode ser usado em múltiplos contextos tais como sistema de acesso às redes digitais, estruturas organizacionais e até mesmo processos que envolvem a produção do conteúdo midiático numa perspectiva mais integrada e não fragmentada, na qual o processo de interação social constrói-se mediante as possibilidades trazidas pela integração dos sistemas, dos dispositivos e das muitas linguagens que podem ser utilizadas de forma articulada. Os sujeitos envolvidos têm a total percepção das reações físicas, podendo interagir instantaneamente; em outras palavras, é possível verificar que nestes meios coexistem elementos da linguagem de duas ou mais mídias o que, nas palavras de Pellanda (2001), já 
pode ser caracterizado como um fenômeno da convergência das mídias.

Lev Manovich (2001:114) acredita que a interface molda a própria concepção do ser humano e "determina también el modo en que piensa em cualquier objeto mediático". O autor afirma que a interface impõe sua própria lógica de organizar os dados. Diante desta premissa, podem ser imediatamente observadas as várias facetas da informação que um só receptor vai adquirindo na medida em que passa de uma interface para a outra: de ouvinte a espectador, de espectador a leitor, enquanto vai gradualmente formando sua opinião acerca da realidade a partir da multiplicidade de fontes (Santaella, 1996).

Ou ainda podemos caracterizar este processo de acordo com Serra (2009, s/p):

(...) a convergência visa adaptar um mesmo serviço a diferentes meios de comunicação e tecnologias de rede de acesso, fornecendo aos usuários acesso às informações e aplicações em qualquer lugar, em qualquer momento, de qualquer rede, por qualquer canal de comunicação, por meio de uma interface homem-máquina coerente com qualidade de serviço adequada e de forma transparente ao usuário.

No entanto, este contexto convergente não se restringe à integração de dispositivos, mas, o reconhecimento da multiplicidade de eventos que envolvem simultaneamente as atividades cotidianas e a superação de fronteiras delimitadas nos processos de aquisição do conhecimento são duas questões fundamentais para uma reflexão sobre as relações entre os indivíduos, a sociedade, o meio social e principalmente as tecnologias ${ }^{6}$.

A Internet, além de apresentar um maior e mais efetivo acesso às informações, pode interferir na forma como estas informações serão utilizadas na aprendizagem de conteúdos significativos. Nestes novos meios, as mensagens veiculadas devido às suas características de fluidez, numeralização, plasticidade e instantaneidade são mais facilmente suscetíveis às interferências dos receptores que podem contribuir diretamente na sua construção e tornaremse também autores-produtores do conhecimento ou dito de outra forma, sujeitos da comunicação e do processo cognitivo.

Jenkins, em seu livro, Cultura da Convergência (2009), também destaca a multiplicidade destas mudanças no âmbito da comunicação. Segundo o autor, a convergência não é apenas um processo tecnológico que une múltiplas funções dentro dos mesmos aparelhos, mas é também um processo de transformação cultural, no qual é possível identificar novos níveis de participação dos fãs, novos laços com os conteúdos, novas orientações para o marketing contemporâneo, novas leis de direitos autorais, novos meios de aferir audiência. Ou seja, dada a multiplicidade de plataformas, os sujeitos são estimulados a procurar

\footnotetext{
${ }^{6}$ Sobre o tema da Multiplicidade, podemos encontrar considerações pertinentes no livro de Ítalo Calvino. Seis propostas para o próximo milênio. SP: Cia das Letras, 1989.
} 
informações, a fazer conexões em meio a conteúdos de mídia dispersos. Em suma, não é a plataforma que converge, mas a mente do sujeito.

Para Jenkins (2009), na cultura da convergência, as velhas e novas mídias colidem, a mídia corporativa e a mídia alternativa cruzam-se. E, reiterando o que diz Santaella (2007), quando surge uma formação cultural nova, esta não leva a anterior ao desaparecimento. Pelo contrário, elas se mesclam e se interpenetram em constante e complexa sobreposição e complementaridade. É fato que a convergência se dá primeiramente pela convergência dos meios de comunicação, pelo fluxo de conteúdos através de diferentes plataformas de mídia e pela migração do público para as diferentes opções disponíveis dependendo da sua necessidade, interesse e da sua disponibilidade e tempo para acesso. No entanto, é o sujeito quem irá decidir o uso mais conveniente e adequado dos dispositivos em função do que ele deseja realizar naquele momento. Por exemplo, para responder mensagens curtas via e-mail, o celular pode ser utilizado de forma satisfatória, no entanto, se ele pretende redigir um texto longo, com muitas informações e detalhes, com certeza fazer isso no computador será mais proveitoso.

Além disso, há, na convergência, um acirramento do conceito de "inteligência coletiva" (Lèvy, 1993), no qual o conhecimento de um determinado assunto é construído a partir do envolvimento das muitas partes presentes no processo de comunicação. Esta interação constante é que garante a compreensão ampliada de um determinado produto cultural oferecido. Como potencialidade da inteligência coletiva e da conectividade temos a emergência de uma nova forma de aprender e ensinar baseada na diversidade de opiniões e na realização de múltiplas tarefas simultaneamente para a construção do conhecimento.

Outro conceito que também define a convergência é a cultura participativa. O fluxo crescente de informações exige que cada vez mais os sujeitos discutam sobre as mídias que consomem. A estrutura que a web disponibiliza para o sujeito permite que este tenha vários níveis de interação e comunicação, ou seja, é possível interagir e se comunicar por meio de uma simples troca de e-mails, até videoconferências e hipertextos, isto torna mais eficaz e espontânea a navegação pelo ciberespaço.

Para tanto, os celulares, enquanto dispositivos móveis, por exemplo, podem ser pensados como interface promissora, não apenas para fins estéticos de personificação, mas também para funções educativas (mobile learning), viabilizando versões originais de interfaces existentes de ambientes de aprendizagem, garantindo uma experiência diferenciada e um melhor aproveitamento da navegação, até mesmo agregando funções que podem potencializar laços afetivos a serem construídos nesses espaços virtuais. Sendo assim, é interessante refletir sobre a forma como esta cultura 
participativa está revitalizando o processo tradicional de construção do conhecimento, como os educadores estão reavaliando o valor da educação informal e como os sujeitos estão aplicando as suas habilidades como fãs e jogadores (gamers) em diferentes instâncias sociais: trabalho, família, escola e política.

Em suma, não há como copiar modelos anteriores, é preciso criar e adaptar novas metodologias para as práticas educativas, a partir dos caminhos já traçados pelas novas possibilidades trazidas pela inteligência coletiva e pela cultura participativa.

\section{Educação Aberta em tempos de Convergência e Inteligência Coletiva}

O foco desta discussão não pode residir apenas no acesso atrelado à reforma tecnológica, mas sim, na participação que envolve os protocolos e práticas culturais e sociais. É preciso considerar a complexidade desta transição. "Os velhos meios de comunicação nunca morrem, nem desaparecem, o que morre são as ferramentas que usamos para acessar seu conteúdo" (Jenkins, 2009: 41) o que morre são as tecnologias de distribuição.

À medida que se amplia a contextualização no processo educacional mediada pelas tecnologias e compreendendo a convergência tecnológica como uma transformação cultural que vai além da integração de dispositivos técnicos, é fundamental discutir mais profundamente as implicações deste novo cenário na Educação. Observamos mais especificamente o potencial das propostas metodológicas e de elaboração de conteúdos digitalmente expandidos que permitam uma compreensão ampliada de significado, independentemente dos caminhos da leitura, e que, ao mesmo tempo, garantam ao sujeito, em se deparando com uma parte, compreender o todo satisfatoriamente. Sendo assim, cada fragmento é independente dos outros, ainda que exista uma relação contextualizada entre eles, seu produto final é genuíno e sua linguagem fundamenta-se na multimidialidade e hipertextualidade.

Este tipo de conteúdo é potencialmente adequado para a Educação Aberta, no sentido em que esta propõe o uso de materiais didáticos com licenças e termos flexíveis, além de padrões e protocolos abertos (Amiel, 2012). Compreendemos por Educação Aberta aquela que se constrói através de protocolos livres de comunicação fazendo uso conteúdos e materiais disponibilizados de forma livre e flexível, facilitando assim a colaboração e interatividade, além de assegurar seu reuso, revisão, redistribuição, remixagem. Trata-se principalmente de conceber mudanças em nossas expectativas e potencialidades para repensarmos o papel das instituições de ensino. De acordo com Tel Amiel (2012: 29): 
"práticas, recursos e ambientes abertos podem nos ajudar a definir de maneira transparente e colaborativa a escola que queremos".

A Educação Aberta possui um conjunto de práticas que a caracteriza, trazendo aspectos exclusivos a depender do contexto. Tais práticas estão pautadas nos itens a seguir:

-a liberdade do estudante decidir onde estudar, podendo ser de sua casa, do seu trabalho ou até mesmo da própria instituição de ensino e/ou polos de aprendizagem;

-a possibilidade de se estudar por módulos, acúmulo de créditos ou qualquer forma que permita ao estudante aprender de forma compatível com o ritmo necessário para seu estilo de vida;

-a utilização da autoinstrução, com reconhecimento formal ou informal da aprendizagem por meio de certificação opcional;

-a isenção de taxas de matrícula, mensalidades e outros custos que seriam considerados uma barreira ao acesso à educação formal;

-a acessibilidade dos cursos para alunos portadores de alguma deficiência física, bem como dos que têm alguma desvantagem social;

-a provisão de recursos educacionais abertos, utilizados tanto na educação formal quanto na informal (Santos, 2012: p. 72).

Com essa cultura surge a produção e reutilização de conteúdos e estabelecese o conceito de Recursos Educacionais Abertos. Segundo definição dada pela UNESCO (2011), REA são materiais de ensino, aprendizado e pesquisa, em qualquer suporte ou mídia, que estão sob domínio público, ou estão licenciados de maneira aberta, permitindo que sejam utilizados ou adaptados por terceiros. $\mathrm{O}$ uso de formatos técnicos abertos facilita o acesso e o reuso potencial dos recursos publicados digitalmente.

O elemento chave que distingue um REA de qualquer outro recurso educacional é a sua licença. Portanto, um REA é simplesmente um recurso educacional com uma licença que facilita o seu reuso - e, possivelmente, adaptação - sem necessidade de solicitar a permissão do detentor sem direitos autorais. (Santos, 2013: 21)

Recursos Educacionais Abertos podem incluir cursos completos, parte de cursos, módulos, livros didáticos, artigos de pesquisa, vídeos, imagens, testes, software, e qualquer outra ferramenta, material ou técnica que possam apoiar o acesso ao conhecimento. Ou seja, REA caracteriza-se como um conteúdo que pode estar em diferentes plataformas, é compartilhado e pode ser editado/ complementado por qualquer pessoa que tenha interesse neste, e através dessa cooperação este conteúdo fica cada vez mais extenso e completo. 
Faz-se então necessário compreender que, promover tal abertura na educação dentro do ciberespaço é fazer uso de série de métodos que garanta ao estudante maior acessibilidade a educação. Os REA, tal como definidos pela Unesco (2011), são "materiais de ensino, aprendizado e pesquisa em qualquer suporte ou mídia, que estão sob domínio público, ou estão licenciados de maneira aberta, permitindo que sejam utilizados ou adaptados por terceiros". Em suma, um recurso de livre acesso e edição, podendo ser remixado e disponibilizado para que este processo continue a se repetir na rede. De acordo com a Declaração da cidade do Cabo, em 2007 :

\begin{abstract}
“(...) a educação aberta não está limitada a apenas recursos educacionais abertos. Também se baseia em tecnologias abertas que facilitam a aprendizagem colaborativa e flexível e à partilha de práticas de ensino que capacitam educadores para beneficiar-se das melhores ideias de seus colegas. Ele também pode crescer para incluir novas abordagens de avaliação, acreditação e aprendizagem colaborativa. Compreender e adotar inovações como estas é fundamental para a visão de longo prazo deste movimento".
\end{abstract}

Conforme Okada (2011), a transição da web 1.0 para web 2.0 trouxe mudanças nas práticas e maneiras de aprender, visando autonomia, coautoria e socialização. "Essa transição exige uma mudança do conceito de "elearning" aprender focado no acesso de recursos digitais, para o conceito de "colearning 2.0" - coaprender com base nas múltiplas coautorias" (Okada, 2011; 130). Com isso, propomos a inclusão deste novo cenário no meio educacional para o aluno tornar-se sujeito autônomo de sua aprendizagem, produzindo e/ou colaborando na produção de conteúdos, seja para a educação formal ou informal.

A educação deve organizar-se em torno de quatro aprendizagens fundamentais que, ao longo de toda a vida, serão de algum modo para cada indivíduo, os pilares do conhecimento: aprender a conhecer, isto é adquirir os instrumentos da compreensão; aprender a fazer, para poder agir sobre o meio envolvente; aprender a viver juntos, a fim de participar e colaborar com os outros em todas as atividades humanas; finalmente aprender a ser, via essencial que integra as três precedentes. (Delors; Eufrazio, 1998: 11)

Os REAs são todo tipo de conteúdo de ensino, aprendizado e pesquisa que esteja em qualquer plataforma de mídia. Esses conteúdos são disponibilizados com licença aberta para que outros sujeitos, além do primeiro "autor", possam contribuir na construção daquele conteúdo. Uma das formas de garantir a circulação destes materiais são as licenças Creative Commons.

Por sua vez, a essência do Creative Commons (CC) vem da palavra commons, que em inglês significa comum ou popular, tendo relação com lugares comuns a todos, como praças, parques, vias públicas, praias e, até mesmo, as 
obras em domínio público, ou seja, commons é aquilo que todos podem usar sem precisar pedir a permissão de ninguém (Lemos, 2005). É o que se pode denominar no direito de bens coletivos ou bens públicos.

OCC é utilizado como um sistema em que funcionam várias licenças dispostas de maneira a proporcionar maior liberdade de circulação com maior proteção ao autor de acordo com o seu interesse. É o autor que escolhe como vai ser regulada a licença. A partir do uso do CC, o autor de qualquer obra intelectual como textos, fotos, músicas, filmes, banco de dados, software ou qualquer outra obra passível de proteção pelo direito autoral, pode licenciar suas obras por meio da licença pública que julgar adequada, autorizando, dessa forma, que a coletividade use suas obras dentro dos limites da licença escolhida pelo autor. Por isso o CC é chamado de projeto colaborativo e admite licença para qualquer obra criativa.

As licenças CC que abrangem possibilidades entre a proibição total dos usos sobre uma obra (todos os direitos reservados) e o domínio público (nenhum direito reservado). Trata-se, pois, de um meio termo (alguns direitos reservados). Assim, o autor que optar por alguma licença CC conserva seu direito autoral ao mesmo tempo em que permite certos usos de sua obra.

Do processo de construção destes recursos educacionais abertos com licença $\mathrm{CC}$, os REAs emergem algumas potencialidades consoantes à cultura da convergência e às novas formas de expressão e de pensamento que se configuram neste cenário, uma vez que permite ao sujeito tornar-se coautor de determinado conteúdo, promove o desenvolvimento da autonomia do sujeito tanto para produzir conteúdos quanto para buscar conteúdos que expandam seu conhecimento sobre determinado tema e estimula o trabalho colaborativo que pode haver entre sujeitos com interesses em comum.

\section{Considerações finais}

Como intuito, este artigo buscou refletir sobre o tema da liberdade de pensamento e posteriormente de expressão, como proposta inicial para a construção da autonomia do sujeito. Parte de uma contextualização histórica do conceito de expressão em sua primeira concepção libertária/individualista, apresentando seu marco político-jurídico até a sua segunda concepção democrática/institucional. Em seguida, conclui que sobre a liberdade de expressão gravitam; a autonomia, a decidibilidade e a auto-direção política da sociedade, também reforçadas em documentos político-jurídicos.

Sem embargo, da liberdade de expressão não se podem afastar os meios de comunicação/expressão. Por isso, o texto reflete uma sintética memória evolutiva dos processos comunicacionais e das formas/padrões de pensamento, por estes engendrados, até chegar ao advento Internet. Desta tecnologia, em função de suas 
características emergem novos paradigmas, novas ferramentas de comunicação, novos tipos de inteligência, que são proporcionados e fomentados.

De fato, as relações midiatizadas pela tecnologia da Internet possuem as condições favoráveis para a ocorrência das três implicações do conhecimentoemancipação desenvolvidas por Boaventura Santos (2002): i) multiculturalismo, vez que todos os partícipes contribuem horizontalmente para a produção do conhecimento, afastando o silêncio e a diferença; ii) conhecimento edificante com a preocupação dos efeitos da tecnologia; iii) não conformismo, com a divulgação de ideias e soluções alternativas, contrárias ao conhecimentoregulador, dominante e excludente.

A teorização crítica da emancipação social (Santos, 2002) está intimamente relacionada com a filosofia da libertação (Dussel, 2002) que defende a relação de diálogo entre as pessoas para que o conhecimento não seja imposto e sim remodelado em conformidade com o contexto social, evitando assim a hegemonia. Efetivamente, a informatização das relações intersubjetivas, ao ampliar e maximizar os espaços para o fluxo de informações ideias e pensamentos, contribuiu para o acréscimo dos pontos de conexão entre a liberdade de expressão e os demais direitos humanos, que têm por escopo a autonomia.

Nesse sentido, o diálogo da liberdade de expressão com os demais direitos humanos está articulado a partir de duas perspectivas: a primeira concebendo esta conexão como um instrumento de meditação, promoção e desenvolvimento dos direitos humanos, e a segunda, sem pretensões de indicar a adequada argumentação de solução e os conflitos de interesse resultantes deste encontro. A garantia da liberdade de expressão, à luz desta teoria crítica, acarreta a libertação e desenvolvimento dos sujeitos, na medida em que estabelecem diálogos horizontais e emancipatórios. A liberdade de expressão, pois, acarreta o empoderamento dos sujeitos tornando-os capazes "de lutar contra qualquer situação que impossibilite esta capacidade de criar, significar e ressignificar as instituições socialmente construídas" ampliando a concepção dos direitos humanos além da sua noção formalista, positivista, estatal, pós-violatória e delegatória (Rubio, 2013: 166).

A ideia principal é subverter a ideia de ver o mundo a partir de um suposto centro, pois isto pressupõe entender a realidade como algo inerte, passivo; algo ao que se terá que dar forma a partir de um raciocínio que lhe é alheio. É preciso ver o mundo desde a periferia, o que implica em reconhecer que mantemos relações que nos mantêm amarrados tanto interna quanto externamente a tudo e a todos. A solidão do centro pressupõe a dominação e violência. A pluralidade das periferias nos conduz ao diálogo e à convivência (Herrera Flores, 2009: 157).

Destas considerações, depreende-se que a liberdade de expressão e a sua interação com os direitos humanos vista nesta atual geografia humana desenhada pela mobilidade, acessibilidade, conectividade e construção colaborativa da 
coletividade, denominada de ciberespaço (Lèvy, 1999; Castells, 2003) é o locus em que está emergindo um novo espírito coletivo, um novo ethos delineado pelas tecnologias de comunicação da Internet, como admite Pérez Luño (2002).

Ao descrever sobre as características do cenário da cultura convergente e suas potencialidades para a Educação Aberta, buscou-se apresentar horizontes futuros e desafios para a construção de novas subjetividades, a partir de novas metodologias e reflexões no campo educacional. A Educação, neste sentido, não pode se furtar de estar no contexto que o influencia o sujeito, que o instrumentaliza e o educa. A expectativa de uma maior democratização da sociedade requer uma melhor utilização dos meios, sem separar as potencialidades da tecnologia da informação e comunicação das vontades individuais e sociais que as pessoas promovem.

Corrobora-se a ideia de que somente com o reconhecimento das peculiaridades das novas formas de expressão, pensamento e comunicação provenientes destes interstícios espaço-temporais constituídos pelos sujeitos, é que podemos pensar a Educação de forma coerente, e buscar a construção de relações e interações sociais que promovam a formação de sujeitos mais autônomos, críticos, dotados de uma inteligibilidade diferenciada e ampliada sobre o mundo, conscientes de seu papel transformador na sociedade. 


\section{Referências}

Acedo, Sara Osuna. Interatuantes e interatuados na web 2.0. In: Aparaci, Roberto (Coord) (2012). Conectados no ciberespaço. São Paulo: Paulinias. Alexy, R (2008). Teoria dos Direitos Fundamentais. São Paulo: Malheiros.

Amiel, Tel (2012). Educação Aberta: configurando ambientes, práticas e recursos educacionais. In: Santana, Bianca; Rossini, Carolina; Nelson de Lucca Pretto (Coord.) Recursos Educacionais Abertos: práticas colaborativas, políticas públicas. Salvador: EDUFBA; São Paulo: Casa da Cultura Digital.

Aparici, Roberto. Conectividade no ciberespaço. In: Aparici, Roberto (Coord.) (2012). Conectados no ciberespaço. São Paulo: Paulinias.

Aristóteles (2000). Política. trad. Terezinha Monteiro Deutsh. São Paulo: Nova Cultural.

Augè, Marc (1994). Não-lugares: introdução a uma antropologia da supermodernidade. Campinas: Papirus.

Berlin, Isaiah (2002). Estudos sobre a Humanidade. São Paulo: Companhia das Letras.

Bobbio, Noberto (1993). Libertad e igualdad. Barcelona: Paidós.

Bobbio, Noberto (2006). Liberalismo e democracia. trad. Marco Aurélio Nogueira. São Paulo: Brasiliense.

Carvalho, Luis Gustavo Grandinetti Castanho de (1994). Liberdade de Informação e o Direito Difuso à Informação. Rio de Janeiro: Renovar.

Castells, Manuel (1999). A sociedade em rede. São Paulo: Paz e Terra.

Chomsky, Noam; Mitchel, Peter R.; Schoeffel, John (2005). Para entender o Poder: o melhor de Noam Chomsky. Trad. Eduardo Francisco Alves. Rio de Janeiro: Bertrand Brasil.

Corrêa, Elizabeth Saad (2007). Convergência de mídias: metodologias de pesquisa e delineamento do campo brasileiro. Documento de trabalho apresentado no I Colóquio Internacional Brasil-Espanha sobre Cibermeios. Faculdade de Comunicação, Universidade Federal da Bahia, 3 a 7 de Dezembro.

Cretella Júnior, José (1974). Liberdades Públicas. São Paulo: Ed. Bushatsk. Dahl, Robert A. (2009). Sobre a Democracia. Brasília: UnB.

Declaração da cidade do Cabo. (2007). Declaração da cidade do cabo para a Educação Aberta: Abrindo a promessa de Recursos Educacionais Abertos. Cape Town, 2007. Disponível em: hhttp://www.capetowndecla Delors, Jacques; Eufrazio, José Carlos (1998). Educação: um tesouro a 
descobrir. Disponível em: http://www.cursoavancos.com.br/downloads/ material/3.pdf. Acesso em: 26/09/2014.

Dussel, Enrique (1996). The underside of modernity: Apel, Ricoeur, Rorty, Taylor, and the philosophy of liberation. ed. and trans. Eduardo Mendieta, Atlantic Highland, New York: Humanities Press.

Eco, Umberto (2001). Apocalípticos e integrados. São Paulo: Editora Perspectiva.

Freire, Paulo (2011). Pedagogia da autonomia: saberes necessários à prática educativa. São Paulo: Paz e Terra.

Gleick, James (2013). A informação: uma história, uma teoria, uma enxurrada.

1. ed. São Paulo: Companhia das Letras, 2013.

Habermas, Jurgen (2000). O discurso filosófico da modernidade: doze lições. trad. Luiz Sérgio Repa, Rodnei Nascimento. São Paulo: Martins Fontes.

Habermas, Jurgen (2002). A inclusão do outro: estudos de teoria política, trad. George Sperber e Paulo Astor Soethe. São Paulo: Loyola.

Houaiss, Antônio; Villar; Mauro de Salles (2009). Dicionário Houaiss da língua portuguesa. 1. ed. Rio de Janeiro: Objetiva.

Jenkins, Henry (2009). Cultura da Convergência. São Paulo: Aleph.

Johnson, Steve (2001). Cultura da interface: Como o computador transforma nossa maneira de criar e comunicar. Rio de Janeiro: Jorge Zahar.

Larenz, Karl (1993). Derecho justo: fundamentos de ética jurídica. trad. Luiz Diez-Picazo, Madrid: Civitas.

Latour, Bruno (2011). Jamais fomos modernos: ensaio de antropologia simétrica. 2. ed. Rio de Janeiro: Ed. 34.

Lemos, André. Espaço, mídia locativa e teoria ator-rede. "Galaxia" (São Paulo, Online), n. 25 (2013), p. 52-65.

Lemos, André. (2009) Arte e mídia locativa no Brasil. In: Lemos, André; Josgrilberg, Fábio. Comunicação e Mobilidade: aspectos socioculturais das tecnologias móveis de comunicação no Brasil. Salvador: EDUFBA.

Lemos, Ronaldo (2005). Direito, Tecnologia e Cultura. Rio de Janeiro: Editora FGV, Disponível em: http://virtualbib.fgv.br/dspace/handle/10438/2190. Acesso em: 25 jan. 2015.

Leornardi, Marcelo (2005). Responsabilidade civil dos provedores de serviço de Internet. São Paulo: Editora Juarez de Oliveira.

Lèvy, Pierre (1993). As tecnologias da inteligência. São Paulo: Editora. 34.

Lèvy, Pierre (1999). Cibercultura. São Paulo: Editora 34.

Locke, John (2001). Segundo tratado sobre o governo civil e outros escritos: ensaio sobre a origem, os limites e os fins verdadeiros do governo civil. Petrópolis: Vozes.

Machado, J. E. M (2002). Liberdade de Expressão: dimensões constitucionais 
da esfera pública no sistema social. Coimbra: Coimbra Editora.

Manovich, Lev. (2005) El lenguaje de los nuevos médios de comunicación: la imagen en la era digital. Buenos Aires: Paidós comunicación.

Mill, John Stuart (2011). Sobre a liberdade. trad. Pedro Madeira. Rio de Janeiro: Nova Fronteira, 2011.

Miranda, Pontes de (1979). Democracia, liberdade, igualdade: os três caminhos. 2. ed. São Paulo: Saraiva.

Molinaro, Carlos Alberto; Ruaro, Regina Linden, Acoplamento entre Internet e Sociedade, "Revista da AGU", v. 40 (2014), p. 37-58.

Neves, Ricardo (2007). O mundo digital: você já está nele: oportunidades, ameaças e mudanças que estamos vivendo. Rio de Janeiro: Relume Dumará.

Okada, Alexandra. (2011). Colearn 2.0 - Refletindo sobre o conceito de coaprendizagem via REAS na web 2.0. In: Barros, D. M. V.; Neves, C.; Seabra, F.; Moreira, J. A.; Henriques, S. (Orgs.). Educação e tecnologias: reflexão, inovação e práticas. Lisboa: Universidade Aberta - Portugal. p. 120-138.

Paz, Octavio (1991). Convergências: ensaios sobre a arte e literatura. São Paulo: Racco.

Pellanda, Eduardo Campos (2001). A Internet como ambiente de convergência de mídias e criação de linguagem própria. Porto Alegre, PPGCOMPUCRS.

Pérez Luño, Antonio-Enrique. Internet y los derechos humanos. "Derecho y conocimiento: Anuário jurídico sobre la sociedad de la información y del conocimiento", 2 (2002), p. 101-121, (ISSN 1578-8202). Disponível em: $<$ http://www.uhu.es/derechoyconocimiento/DyC02DYC002_A05.pdf $>$ Acesso em 05 jan. 2015.

Pisani, Francis; Piotet, Dominique (2010). Como a web transforma o mundo: a alquimia das multidões. São Paulo, Senac.

Primo, Alex (Coord). (2013). Interações em rede, Porto Alegre: Sulina.

Rosseau, Jean-Jaqcues (1999). O contrato social. trad. Antônio de P. Machado. 19. ed. Rio de Janeiro: Ediouro.

Santaella, Lucia (1996). Cultura das mídias. São Paulo: Experimento.

Santos, Andrea Inamorato. (2011) Open Educational Resources in Brazil: Stateof-the-art, Challenges and Prospects for Development and Innovation. Moscow: UNESCO.

Santaella, Lucia (2007). Linguagens líquidas na era da Mobilidade. SP: Paulus.

Serra, Ana Paula Gonçalves. (2011). Convergência tecnológica em sistema de 
informação. Disponível em: < ftp://www.usjt.br/pub/revint/333_47.pdf > Acesso em: 19/10/2011.

Spadaro, Antônio (2013). Web 2.0: redes sociais. trad. Cacilda R. Ferrante. 1. ed. São Paulo: Paulinas.

Sibilia, Paula (2002). O homem pós-orgânico: corpo, subjetividade e tecnologias digitais. Rio de Janeiro: Relume Dumará. 